\title{
Gallic Acid Content and Antioxidant Activity of Pomegranate Peel Ethanol Extract
}

\author{
Diah Dhianawaty, ${ }^{1,2}$ Latifah Rahman Nurfazriah, ${ }^{2,3}$ Andri Rezano ${ }^{2,4}$ \\ ${ }^{1}$ Division of Biochemistry and Molecular Biology, Department of Biomedical Sciences Faculty of Medicine \\ Universitas Padjadjaran, Indonesia, ${ }^{2}$ Biomedical Sciences Master Program, Faculty of Medicine Universitas \\ Padjadjaran, Indonesia, ${ }^{3}$ Department of Family Welfare Education, Faculty of Engineering, Universitas Negeri \\ Medan, Indonesia, ${ }^{4}$ Division of Cell Biology, Department of Biomedical Sciences Faculty of Medicine
} Universitas Padjadjaran, Indonesia

\begin{abstract}
Ethanol extract of Pomegranate peel is proven to have the ability to inhibit the proliferation of cervical cancer HeLa cells. It was reported that the extract contains ellagic acid, gallic acid, and punicalagin which are identified as major effectors of antitumor activity. Based on the previous statement, the examination on the extract would be carried out by identifying one of the above compounds namely gallic acid. Antioxidant activity can influence cancer cell proliferation, therefore, it will be determined in the extract. This study was performed in Biochemistry and Molecular Biology Laboratory and Central Laboratory Universitas Padjadjaran period of SeptemberDecember 2019. Gallic acid concentration was measured by using a high-performance liquid chromatography method (HPLC) and antioxidant activity was measured by using 1,1-diphenyl-2-picrylhydrazyl (DPPH). The extract contained gallic acid of $616.97 \mathrm{mg} / \mathrm{kg}$ and had an antioxidant activity of IC ${ }_{50} 6.1 \mu \mathrm{g} / \mathrm{mL}$. Based on its activity, gallic acid has cytotoxic and antitumor effects which are generated by its ability to modulate antioxidant/ pro-oxidant balance and inhibit reactive oxygen species (ROS). High activity of antioxidant from the extract is also caused by the existence of gallic acid, which is known as a strong antioxidant. Antioxidants can protect normal cells by lowering ROS levels so that it can protect cells from damages. Therefore, both parameters can be used as parts of markers found in pomegranate peel extract which has activity in inhibiting HeLa cell proliferation.
\end{abstract}

Keywords: Antioxidant activity, gallic acid, peel extract of pomegranate fruit, Punica granatum

\section{Kandungan Asam Galat dan Aktivitas Antioksidan Ekstrak Etanol Kulit Delima}

\begin{abstract}
Abstrak
Ekstrak etanol kulit buah delima terbukti dapat menghambat proliferasi sel kanker serviks (sel HeLa). Ekstrak ini telah dilaporkan mengandung asam ellagat, asam galat, dan punicalagin yang diidentifikasi sebagai efektor utama dari aktivitas anti-tumor. Berdasarkan pernyataan sebelumnya, pemeriksaan ekstrak akan dilakukan dengan mengidentifikasi salah satu senyawa tersebut yaitu asam galat. Aktivitas antioksidan dapat mempengaruhi proliferasi sel kanker, oleh karena itu, akan ditentukan pada ekstrak. Penelitian ini dilakukan di Laboratorium Biokimia dan Biologi Molekuler dan Laboratorium Sentral Universitas Padjadjaran periode September-Desember 2019. Kandungan asam galat diukur dengan metode kromatografi cair kinerja tinggi (KCKT) dan aktivitas antioksidan diukur dengan metode 1,1-difenil-2-pikrilhidrazil (DPPH). Ekstrak mengandung asam galat 616,97 $\mathrm{mg} / \mathrm{kg}$ dan memiliki aktivitas antioksidan IC50 6,1 $\mu \mathrm{g} / \mathrm{mL}$. Berdasarkan aktivitasnya, asam galat mempunyai efek sitotoksik dan antitumor yang dihasilkan oleh kemampuannya untuk memodulasi keseimbangan antioksidan/ pro-oksidan dan menghambat spesies oksigen reaktif. Aktivitas antioksidan yang sangat kuat dari ekstrak juga disebabkan oleh adanya asam galat; asam galat dikenal sebagai antioksidan kuat. Antioksidan mampu melindungi sel normal dengan menurunkan level ROS, sehingga memproteksi sel dari kerusakan. Dengan demikian, kedua parameter tersebut dapat digunakan sebagai bagian dari penanda untuk ekstrak kulit delima yang mempunyai aktivitas menghambat proliferasi sel HeLa.
\end{abstract}

Kata kunci: Aktivitas antioksidan, asam galat, ekstrak kulit buah delima, Punica granatum

Corresponding Author: Diah Dhianawaty, Department of Biomedical Sciences, Division of Biochemistry and Molecular Biology, Faculty of Medicine, Universitas Padjadjaran, Email:dhianawaty@unpad.ac.id 


\section{Introduction}

Ethanol extract of Pomegranate peel is proven to have the ability to inhibit the proliferation of cervical cancer HeLa cells with an IC $\mathrm{I}_{50}$ of $450 \mu \mathrm{g} /$ $\mathrm{mL}$ and reducing the viability of HeLa cells of approximately $52 \%{ }^{1}$

Homeostasis of oxidation-reduction reactions is urgently required by aerobic organisms. The organisms require a balance between the rate and the amount of oxidant production and their reduction at all times. ${ }^{2}$ Redox reactions are important in preserving cellular functions such as metabolic cycles and detoxification of hazardous materials. ${ }^{3}$ The Reactive Nitrogen Species (RNS) and Reactive Oxygen Species (ROS) in mitochondria are specially generated from oxygen metabolism through several endogenous systems, pathological conditions, or exposure to various physiochemical states. ${ }^{3}$ Excessive ROS production beyond the ability of antioxidant defenses or disturbance in redox homeostasis due to overload or deficit condition of either one can cause an oxidative stress in the body. ${ }^{3}$ This condition triggers hazardous effects on the life cycle of biological tissues. ${ }^{3,4}$ Redox imbalance is a factor that causes the oxidative stress condition and cancer cells are found in this condition. A higher ROS levels have been identified in cancer cells, which are caused by high metabolic and peroxisomal activities, mitochondrial dysfunction, cellular signaling, activation of an oncogene, and increased enzymatic activity of oxidases. ${ }^{5,6}$ Therefore, a reduction in metabolic rate can decrease the formation of ROS and may bring advantages to the body. ${ }^{6,7}$

The antioxidant ceases the chain reactions by removing free radical intermediates and prevents other related oxidation reactions. ${ }^{7}$ Antioxidant systems can either avoid the formation of reactive species or eliminate them before they can disrupt the essential components of the cell. However, the ROS has beneficial cellular functions, including redox signaling. Therefore, the antioxidant system does not eliminate all oxidants but maintains them at the optimum level. ${ }^{8}$ Antioxidants inhibit cancer growth through the use of molecular targets, such as molecules that control apoptosis, cell proliferation, differentiation, or cell cycle. These targets can be activated or deactivated, relying on each particular case, thus allowing the initiated cells to survive and proliferate. ${ }^{8}$

Gallic acid is found in some fruits and herbs or medicinal plants. Gallic acid is a compound that belongs to the group's natural phenolic compounds that shows biological and pharmacological activities in vitro and in animal models. Gallic acid and its derivatives have been reported to have several therapeutic activities, such as gastroprotective activity, antimicrobial activity, anticancer activity, and provides cardiovascular protection through the context of its antioxidant efficacy that can reduce harmful effects of free radicals. ${ }^{9}$

Pomegranate is a traditional medicinal plant. The taxonomy of pomegranate can be described as follows: Kingdom: Plantae Plants; Subkingdom: Tracheobionta - Vascular plants; Superdivision: Spermatophyta - Seed plants; Division: Magnoliophyta - Flowering plants; Class: Magnoliopsida-Dicotyledons; Subclass Rosidae; Order: Myrtales; Family: Punicaceae-Pomegranate family; Genus: Punica L.-pomegranate; Species: Punica granatum L.- pomegranate. ${ }^{10}$

Pomegranate trees are useful to treat many diseases. Its flowers can treat bronchitis and bleeding while its flesh is beneficial for aphthous stomatitis, hypertension, etc. The peel is also useful for sore throat, earache, leukorrhea, etc. ${ }^{11}$ Nowadays, pomegranate is an interesting medicinal plant to be studied from the perspective of its secondary metabolites. This study aimed to identify the gallic acid content and measure the antioxidant activities of pomegranate peel ethanol extract.

\section{Methods}

The following materials were used in this study: gallic acid reference standard from Sigma Aldrich; 1.1-diphenyl-2-picrylhydrazyl (DPPH) from Sigma Aldrich; and orthophosphoric acid; methanol; acetonitrile; and Milli Q-water from Merck. All reagents were HPLC grade).

The gallic acid was measured by using Waters Alliance e2695 HPLC while the Coloum: Purospher STAR RP-18e, size: 250x4.6 mm and a mixture of $70 \%$ of $0.1 \%$ of orthophosphoric acid; $10 \%$ of methanol and $20 \%$ of acetonitrile (all were HPLC grade) were used in stationary phase and mobile phase, respectively. Other instruments used were a detector with UV 369 $\mathrm{nm}$. The antioxidant activity was measured by using Eppendorf Biospectrometer Basic AG 22331 Hamburg series: 6135 BJ.

Pomegranate was harvested from Malang, East Java, with the maturity of pomegranate fruit was determined by the farmers. Pomegranate peel was extracted using $70 \%$ ethanol and 
concentrated using a freeze dryer to obtain the concentrated extract and the gallic acid was then characterized by the HPLC method. One hundred milligrams of gallic acid reference standard was dissolved in $100 \mathrm{~mL}$ water and the same protocol was performed on pomegranate peel extract. Then, one microliter of gallic acid reference standard was prepared and injected into the HPLC equipment, which was then run by a mixture of $70 \%$ of $0.1 \%$ of orthophosphoric acid, $10 \%$ of methanol, and $20 \%$ of acetonitrile with a flow rate of $1 \mathrm{~mL} / \mathrm{min}$ in 10 minutes. The same protocol was performed on the pomegranate peel ethanol extract. ${ }^{12}$

The next step was to measure the antioxidant activities of the pomegranate peel extract. Fifty milligrams of pomegranate peel ethanol extract were prepared and dissolved in $25 \mathrm{~mL}$ of methanol. Five concentration variations of $0.375 ; 0.250 ; 0.125 ; 0.0625$ and $0.0312 \mathrm{mg} / 25$ $\mathrm{mL}$ were prepared from this solution. Each extracted sample was mixed with $1 \mathrm{~mL}$ of DPPH and the mixture was stored for 30 minutes. The optical density (absorbance) was measured using a spectrophotometer at $517 \mathrm{~nm}$ wavelength, and the percentage of antioxidant activity (\% $\mathrm{IC}_{50}$ or percentage of half maximal inhibitory concentration expressed as the quantity of the extracts to react with half of DPPH radicals was calculated using a linear regression equation from the DPPH inhibition curve. ${ }^{13}$

Based on the retention time data obtained, the gallic acid concentration in the extract was calculated using the following equation:

Gallic acid in the extract $=$ (legible concentration $x$ injection volume $) /($ sample weight)

The antioxidant activity was calculated with the equation below:
Table Retention Time of Gallic Acid in the Extract

\begin{tabular}{cccc}
\hline $\begin{array}{c}\text { Retention Time } \\
\text { (minutes) }\end{array}$ & Area & \% Area & Height \\
\hline 2.959 & 10867 & 41.09 & 823 \\
4.168 & 15578 & 58.91 & 1614 \\
\hline
\end{tabular}

$\% \mathrm{IC}_{50}=$ (Absorbance of reference-absorbance of sample )/(absorbance of reference) x 100\%

This study was conducted in the period of September-December 2019 at the Central Laboratory Universitas Padjadjaran, and the Biochemistry and Molecular Biology Laboratory, Jatinangor, Indonesia.

This was an experimental study using triplicates and results were reported as the average of all measurements. The study was approved by the Health Ethics Research Committee of the Faculty of Medicine, Universitas Padjadjaran, under an ethical clearance No. 718/ UN6.KEP/AC/2020 issued on August 11, 2020.

\section{Results}

The results of the measurement of gallic acid reference standard by the HPLC method are presented in retention time, as presented in Table 1. The retention time of gallic acid reference was 4.162 min in 25249 area.

The measurement using HPLC presented two retention times, namely $2.959 \mathrm{~min}(1)$ and $4.168 \mathrm{~min}(2)$. One of the two retention times of the sample above showed that $4.168 \mathrm{~min}(2)$ was closest to the reference retention time of

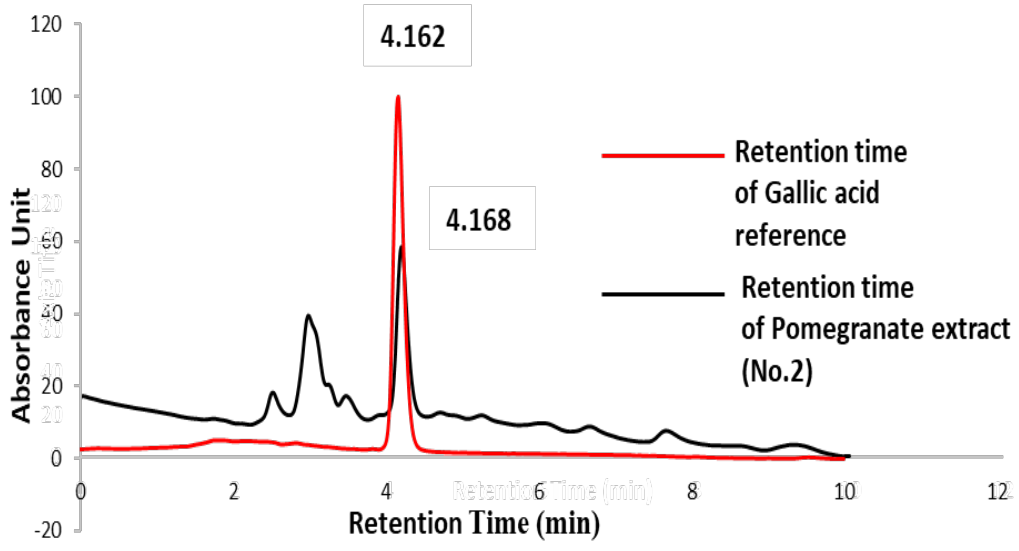

Figure 1 HPLC Chromatograms of Gallic Acid Reference Standard and Pomegranate Ethanol Extract 


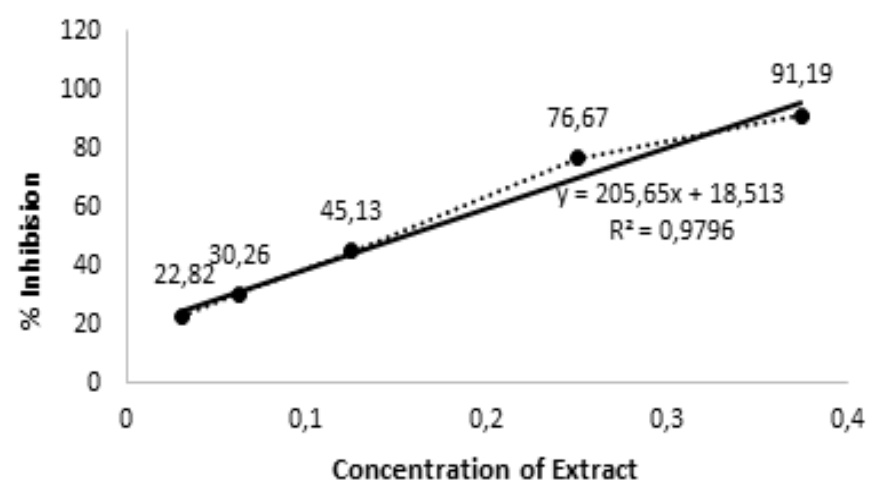

Figure 2 Percentage of Inhibition vs Concentration of Ethanol Extract of Pomegranate

4.162 minutes of gallic acid. The results of both retention times in the reference and the sample are plotted and shown in Figure 1, showing a quite similar times.

The result of gallic acid reference measurement showed a retention time of $4.162 \mathrm{~min}$ while the retention time for the pomegranate peel ethanol extract was $4.168 \mathrm{~min}$ (Table). Thus, the gallic acid concentration in the extract could be calculated based on retention time. Both data were then used to calculate the concentration of gallic acid in the pomegranate peel ethanol extract, resulting in a concentration of gallic acid of $617 \mathrm{mg} / \mathrm{kg}$ extract, showing that the extract really contained gallic acid based on the HPLC results. The antioxidant activity test was then performed on the pomegranate peel ethanol extract using the DPPH method.

The calculation of antioxidant activities was done based on the curve of \% inhibition versus concentration in the sample. The sample concentrations were arranged according to the followings: $0.375,0.25,0.125,0.0625$, and $0.0312 \mathrm{mg}$ in the $25 \mathrm{ml}$ of methanol solution. The measurement was conducted three times for each concentration. The results were then plotted in the form of a percentage of inhibition versus concentration of extract since the result was obtained (Figure 2).

The antioxidant activities of pomegranate peel ethanol extract was calculated using a linear regression equation from the DPPH inhibition curve above (Figure 2), resulting in $y=205.65 x$ +18.513 . By using the regression equation of $y=$ $205.65 x+18.513$, it was determined that the antioxidant activities of the extract was $\mathrm{IC}_{50}=6.1$ $\mu \mathrm{g} / \mathrm{mL}$.

\section{Discussion}

A previous study explained that the pomegranate peel ethanol extract shows activities to inhibit HeLa cell proliferation. This extract has been shown to have an anticancer potential with an $\mathrm{IC}_{50}$, in which less than $100 \mu \mathrm{g} / \mathrm{mL}$ HeLa cells treated with the extract undergo apoptosis. Apoptosis is shown by cell morphological abnormalities; DNA and protein condensation and fragmentation; decreased Bcl-2 protein; and increased Bax protein. ${ }^{1}$

Another thing that was highlighted in this previous study was the phytochemical content of the extract. The phytochemical screening showed that the extract containsseveral compounds, flavonoids, quinones, saponins, tannins, and triterpenoids/steroids. ${ }^{1} \quad$ Previous studies reported that the pomegranate peel contains many secondary metabolites such as punicalin, punicalagin, gallic acid, ellagic acid, caffeic acid, ellagitannins, pelletierine alkaloids, kaempferol, luteolin, and quercetin. ${ }^{14}$

The concentration of secondary metabolites such as gallic acid, ellagic acid, punicalagin, and others is influenced by many factors, including the type of extraction solvent. Solvents include water, ethanol, acetone, and diethyl ether both alone or in combination that are used to extract the secondary metabolites. The HPLC analysis showed a mixture of water, diethyl ether, and ethanol (1:1:8) extracting punicalagin $\mathrm{A}$, punicalagin B, ellagic acid, and gallic acid in a higher concentration than other solvents. ${ }^{15}$

Some of these compounds were reported to have anticancer activities. One of the compounds is gallic acid with HeLa cancer cells inhibition activities. ${ }^{16}$ This present study is actually the 
continuation of the previous study to explore the secondary metabolites with an antitumor activity, namely gallic acid, as analyzed using the HPLC method.

Gallic acid reference standard measurement showed a retention time of $4.162 \mathrm{~min}$. A similar retention peak/time was seen in pomegranate peel ethanol extract at $4.16 \mathrm{~min}$. Based on the similarity of both retention times it can be proven that the extract contains gallic acid. The concentration of gallic pomegranate peel ethanol extract was $617 \mathrm{mg} / \mathrm{kg}$ extract.

As described above, gallic acid can employ its cytotoxic and antitumor effect through the modulation of antioxidant/pro-oxidant balance. In some conditions, the reactive oxygen species (ROS)-induced carcinogenesis can be controlled by gallic acid, with its ability to increase the activity of superoxide dismutase (SOD), glutathione reductase (GR), glutathione peroxidase (GPx), and catalase (CAT), and/or to reduce ROS production and the lipid peroxidation. On the contrary, gallic acid can activate the caspases pathway and ROS generation, which can induce cell cycle arrest, autophagy, and apoptosis. Moreover, it can impede invasion and metastasis by declining the matrix metalloproteinase expression and activity. Hence, gallic acid can cause apoptosis of the cancer cell, supported the inhibitory activity of HeLa cell proliferation generated by the extract. ${ }^{9,14,16,17}$

The oxidative stress is defined as a state of pro-oxidant/antioxidant imbalance. The natural antioxidants can remove the ROS. In addition to gallic acid, these antioxidants include hydrogen peroxide, superoxide anions, hypochlorous acid, and hydroxyl radicals. Previous studies have explained that antioxidant can show an advantageous effect in treating distinctive diseases. ${ }^{9,18}$

The result of the presence study shows an antioxidant activity of the extract with the $\mathrm{IC}_{50}=6.1 \mu \mathrm{g} / \mathrm{mL}$, meaning pomegranate peel ethanol extract has a highly effective antioxidant activity. ${ }^{18}$ This is in line with the findings of a study by Samad et al. stating that gallic acid is a powerful natural antioxidant. ${ }^{18}$ Antioxidant/ detoxifying compounds have been known as a defensive system against oxidative stress that decreases reactive species. The compounds can maintain normal cells from Exo-/endogenous oxidative damages and reduce the coetaneous carcinogenesis chance successfully. ${ }^{19}$

In conclusion, the pomegranate peel ethanol extract contains gallic acid $(617 \mathrm{mg} / \mathrm{kg}$ of extract) and has highly effective antioxidant activity ( $\mathrm{IC}_{50}=6.1 \mu \mathrm{g} / \mathrm{mL}$ ). This will enhance the antiproliferative activity on the HeLa cervical cancer cells. Therefore, in the effort to create an extract for this purpose, the gallic acid content and antioxidant activity can be used as two markers that show the ability to the proliferation of HeLa cancer cells. However, there are several limitations to this study. Gallic acid is one of many compounds that has inhibitory activity on cancer cells. Isolation of gallic acid from the extract was not conducted in this study, thus the result must be interpreted carefully.

\section{References}

1. Rezano A, Nurfazriah LR, Istiqomah AA, Dhianawaty D. Cytotoxicity effect of pomegranate peel extract against cervical cancer HeLa cells. In: Zulham, Ichwan M, editor. Proceedings of the Second National Scientific Meeting of Indonesian Consortium of Biomedical Sciences; 2017 November 2324; North Sumatra, Indonesia. Medan: KIBI; 2017. p. 105-11.

2. Panieri E, Santoro MM. ROS homeostasis and metabolism: a dangerous liason in cancer cells. Cell Death Dis. 2016;7(6):e2253.

3. FFraunberger EA, Scola G, Laliberté VL, Duong A, Andreazza AC. Redox Modulations, Antioxidants, and Neuropsychiatric Disorders. Oxid Med Cell Longev. 2016;2016: 4729192.

4. Roy J, Galano JM, Durand T, Le Guennec JY, Lee JC. Physiological role of reactive oxygen species as promoters of natural defenses. FASEB J. 2017;31(9):3729-45.

5. Kumari S, Badana AK, Mohan GM, Shailender $\mathrm{G}$ and Malla RR. Reactive oxygen species: a key constituent in cancer survival. Biomark Insights. 2018;13: 177271918755391.

6. Aggarwal V, Tuli HS, Varol A, Thakral F, Yerer MB,SakK, etal. Review: Role ofreactive oxygen species in cancer progression: molecular mechanisms and recent advancements. Biomolecules. 2019;9(11):735

7. He L, He T, Farrar S, Ji L, Liu T, Maa X. Review: Antioxidants maintain cellular redox homeostasis by elimination of reactive oxygen species. Cell Physiol Biochem. 2017;44:532-53.

8. Mudie K, Gebregzabher A, Kassa D. Investigation of the biochemical mechanism of action of antioxidants in the prevention of cancer. IntJ Pharm Sci Res. 2015;6(11):455669. 
9. Kahkeshani N, Farzaei F, Fotouhi M, Alavi SS, Bahramsoltani R, Naseri $R$, et al. Pharmacological effects of gallic acid in health and diseases: A mechanistic review. Iran J Basic Med Sci. 2019;22(3):225-37.

10. USDA; United States Department of Agriculture. Punica granatum L. [Internet] 2020 [cited 2020 November 17]. Available from: https://plants.usda.gov/java/ tionServlet? source $=$ display\&classid=PUNIC.

11. Dalimartha S. Punica granatum L. In: Rohmawati $\mathrm{T}$, Sudarmanto PT, Jumanta, editor. Atlas tumbuhan obat Indonesia. $3^{\text {th }}$ ed. Depok: Puspa Swara; 2010. p. 8-15.

12. Kardani K, Gurav N, Solanki B, Patel P. RPHPLC method development and validation of gallic acid in polyherbal tablet formulation. J Appl Pharm Sci. 2013;3(5):37-42.

13. Dhianawaty D, Ruslin. Kandungan total polifenol dan aktivitas antioksidan dari ekstrak metanol akar Imperata cylindrica (L) beauv. (alang-alang). MKB. 2015;47(1):60-4.

14. Sreekumar S, Sithul H, Muraleedharan P, Azeez JM, Sreeharshan S. Review: Pomegranate fruit as a rich source of biologically active compounds. BioMed Res Int. 2014;2014:686921.

15. Singh M, Jha A, Kumar A, Hettiarachchy N, Rai AK, Sharma D. Influence of the solvents on the extraction of major phenolic compounds (punicalagin, ellagic acid and gallic acid) and their antioxidant activities in pomegranate aril. J Food Sci Technol. 2014;51(9):2070-77.

16. Aborehab NM, Osama N. Effect of Gallic acid in potentiating chemotherapeutic effect of Paclitaxel in HeLa cervical cancer cells. Cancer Cell Int. 2019;19:154.

17. Walton EL. The dual role of ROS, antioxidants and autophagy in cancer. Biomed J. 2016; 39:89-92.

18. Samad N, Javed A. Therapeutic Effects of Gallic Acid: Current Scenario. J Phytochemistry Biochem. 2018;2:113.

19. Gholamian-Dehkordi N, Luther T, AsadiSamani M, Mahmoudian-Sani MR. An overview on natural antioxidants for oxidative stress reduction in cancers; a systematic review. Immunopathol Persa. 2017;3(2):e12. 